\title{
IMPLEMENTATION OF FINDINGS OF GENERATION THEORIES IN ENGINEERING STUDIES
}

\author{
Regina Baltusite, Baiba Briede \\ Latvia University of Life Sciences and Technologies, Latvia \\ rilagora@inbox.lv, baiba.briede@1lu.lv
}

\begin{abstract}
M. McCrindledetermined generation borders and defined them sociologically.A lot of answers were found out about the peculiarities of nowadays students initiating changes in the study process at a higher school and education in general. The aim of the article is to assess the findings of generation theories and to analyze the opportunities of their implementation in higher education, and particularly in engineering studies. Cultural, historical, technological differences and their cross-influenceare analysed in the article in the context typical for each generation. Particular attention is paid to Generation Zbelonging students' habits and values. It is stressed in the article that Generation's Z challenges will be life in a dinamically changing world with various catastrophies, ecological and demographic crises, development of IT, including artificial intelligence as well as opportunities to choose the form of work (distance, at any time, regular). One of the main tasks of Generation $\mathrm{Z}$ will be to take complex decisions and solve problems for dynamically changing uncertain future. Therefore, a study at Jelgava Secondary School No. 5 had been carried out. The survey reflected answers of 55 respondents on motives of the choice of a profession and work values. 77 Latvia University of Life Sciences and Technologies (LLU) first year engineering students' survey was done on their spending time in the Internet, relations with authoritarian teachers and expression of ideas freely.41educators of the LLUparticipated in the study analysing their strong and weak sides, opportunities and threats in relation to Generation Z. Studies had been done in the period from 2016 to 2018. Considering the theoretical and empirical results recommendations for the improvement of engineering studies were worked out.
\end{abstract}

Keywords: generation theories, Generation Z, engineering studies.

\section{Introduction}

The World Economic Forum's 2018 initiatives touched the challenges of systems from local/regional to global ones. The stress was put on the interaction of systems and their mutual influence. System initiatives covered such themes as: consumption; digital economy and society; economic progress; education, gender and work; energy; environment and natural resource security; financial and monetary systems, food security and agriculture; health and healthcare; information and entertainment; international trade and investment; production; long-term investing, infrastructure and development; mobility and other ones. The challenge of the systems is that the impact should be positive towards all economies, not only big ones, and environmental and natural security should be kept at the same time [1].

The system initiatives is a huge challenge, because it demands the change of thinking from local/national interests towards understanding the economic, political, social, ecological systems as global entirety. It means that young generations particularly need holistic and systemic thinking and self-, professional and social competence to navigate economies and societies successfully to keep sustainability and meet common national and global aims.

The World Economic Forum 2018 in relation to the future education, gender and work put stress on the development of talent and its maximal usage for the benefit of society and economy. It means that a new way of leadership should be developed, where collaboration of leaders from entrepreneurship, local authorities and national governments and society in general will be necessary. Stakeholders will need new knowledge and dialogue skills to implement common aims locally and globally [2].

Generation $\mathrm{Z}$ will be involved in global systemic processes and take responsibilities for successful overcoming of challenges. The problem on mutual relations of generations and values will be topical as well, because people will be obliged to work together in various types of nets.

Researches in different countries affirm that relations among generations have an impact on all fields of life [3-6].Humans born from 1995 to 2010(2012) belong to Generation Z [3-6]. Researchers of generation development view that the main fields of occupation of Generation $\mathrm{Z}$ will be: robot technologies, bioengineering, information technologies (IT), medicine, etc. [5]. It means that many fields belong to engineering or are closely related to it. Therefore, engineering sciences are topical 
both in secondary and higher education. Generation $\mathrm{Z}$ will meet the challenges of the $21^{\text {st }}$ century and educators have to consider several fields in order to help that generation to reach an appropriate competence. The fields of importance are peculiarities of Generation $\mathrm{Z}$ in close relation to the teaching/learning process organization and methods. That is why the aim of the article is to assess the findings of generation theories and to analyze the opportunities of their implementation in higher education, and particularly in engineering studies.

\section{Materials and methods}

Three empirical studies are analysed in the article.

As regards research on Generation $\mathrm{Z}$ in Latvia, there has been carried out a study at Jelgava secondary school No. 5 by the student of form 11 D. Bistricka under the supervision of R. Baltusite. The study was on motives of the choice of a profession and work values. 55 respondents (belonging to Generation Z) from forms 11 (29 respondents) and 12 (26 respondents) participated in the study. Work values questionnaire [7] was used in the study in January 2018.

Two groups of the LLU educators (41 persons) in 2016 and 2017 described themselves in relation to Generation $\mathrm{Z}$ by the SWOT analysis. The results of two years are compiled into four groups: strong sides, weak sides, opportunities and threats. According to SWOT strong and weak sides reflect inner condition/state and opportunities and threats reflect outer conditions.

The survey reflecting 77 engineering students' self-assessment of spending time in the Internet, relations with authoritarian teachers and expression of ideas freelyhadbeen carried out in 2016. The survey questions were chosen according to the traits of Generation Z. Ranged answer choices were in the questionnaire. Students marked high (h), medium (m) and low (l) levels. There were compared the data and their difference of significance using the Chi-square test in determination of the $\mathrm{p}$ value $(p \leq \alpha=0.05)$.

\section{Results and discussion}

The theory of generations was activated again in the nineties of the $20^{\text {th }}$ century. The following names of generations are known in nowadays labour market: Builders, Baby Boomers, Generation X, Generation Y and Generation Z. M. McCrindle determined the following generation borders in years: Builders - 1925 - 1945; Baby Boomers - 1946 - 1964; Generation X - 1965 - 1979; Generation Y 1980 - 1994; Generation Z - 1995 - 2010. The author compiled the factors influencing each generation: Aust PM's, Iconic Technology, Music, Popular Culture, Social Markers/Landmark Events, Influencers, Training Focus, Learning Format, Learning Environment, Sales\&Marketing, Purchase Influences, Financial Values, Ideal Leaders [3]. The factors influencing studies at higher schools, including engineering studies, as well from the point of view of the generation's theory are reflected in Table $1[3]$.

Table 1

Generation Defined Sociologically

\begin{tabular}{|c|c|c|c|c|c|}
\hline Property & Builders & $\begin{array}{c}\text { Baby } \\
\text { Boomers }\end{array}$ & Generation X & Generation Y & Generation Z \\
\hline $\begin{array}{c}\text { Iconic } \\
\text { Technology }\end{array}$ & $\begin{array}{c}\text { Radio(Wireless) } \\
\text { Motor Vehicle } \\
\text { Aircraft }\end{array}$ & $\begin{array}{c}\text { TV, Audio } \\
\text { Cassette, } \\
\text { Transistor } \\
\text { Radio }\end{array}$ & $\begin{array}{c}\text { VCR, } \\
\text { Walkman, } \\
\text { IBM PC }\end{array}$ & $\begin{array}{c}\text { Internet, } \\
\text { Email, SMS, } \\
\text { DVD, } \\
\text { PlayStation, } \\
\text { Xbox, iPod }\end{array}$ & $\begin{array}{c}\text { MacBook, } \\
\text { iPad, Google, } \\
\text { Facebook, } \\
\text { Twitter, } \\
\text { WiFi,PS3, } \\
\text { Android }\end{array}$ \\
\hline $\begin{array}{c}\text { Influencers } \\
\text { Training } \\
\text { Focus }\end{array}$ & $\begin{array}{c}\text { Authority } \\
\text { Officials }\end{array}$ & $\begin{array}{c}\text { Evidential } \\
\text { Expert }\end{array}$ & $\begin{array}{c}\text { Pragmatic } \\
\text { Practitioners }\end{array}$ & $\begin{array}{c}\text { Experiential } \\
\text { Peers }\end{array}$ & $\begin{array}{c}\text { User- } \\
\text { generated } \\
\text { Forums }\end{array}$ \\
\hline Top- down & $\begin{array}{c}\text { Technical } \\
\text { Data } \\
\text { Evidence }\end{array}$ & $\begin{array}{c}\text { Practical } \\
\text { Case studies } \\
\text { Applications }\end{array}$ & $\begin{array}{c}\text { Emotional } \\
\text { Stories } \\
\text { Participative }\end{array}$ & $\begin{array}{c}\text { Multi-modal } \\
\text { eLearning } \\
\text { Interactive }\end{array}$ \\
\hline
\end{tabular}


Table 1 (continued)

\begin{tabular}{|c|c|c|c|c|c|}
\hline Property & Builders & $\begin{array}{c}\text { Baby } \\
\text { Boomers }\end{array}$ & Generation X & Generation Y & Generation Z \\
\hline $\begin{array}{c}\text { Learning } \\
\text { Format }\end{array}$ & $\begin{array}{c}\text { Formal } \\
\text { Instructive }\end{array}$ & $\begin{array}{c}\text { Relaxed } \\
\text { Structured }\end{array}$ & $\begin{array}{c}\text { Spontaneous } \\
\text { Interactive }\end{array}$ & $\begin{array}{c}\text { Multi-sensory } \\
\text { Visual }\end{array}$ & $\begin{array}{c}\text { Student- } \\
\text { centric } \\
\text { Kinesthetic }\end{array}$ \\
\hline $\begin{array}{c}\text { Learning } \\
\text { Environment }\end{array}$ & $\begin{array}{c}\text { Military style } \\
\text { Didactic\& } \\
\text { disciplined }\end{array}$ & $\begin{array}{c}\text { Classroom } \\
\text { style } \\
\text { Quiet } \\
\text { atmosphere }\end{array}$ & $\begin{array}{c}\text { Round-table } \\
\text { style } \\
\text { Relaxed } \\
\text { ambience }\end{array}$ & $\begin{array}{c}\text { Cafe style } \\
\text { Music\& } \\
\text { multi-modal }\end{array}$ & $\begin{array}{c}\text { Lounge room } \\
\text { style } \\
\text { Multi-stimulus }\end{array}$ \\
\hline Ideal Leaders & Authoritarian & $\begin{array}{c}\text { Commanding } \\
\text { Thinkers }\end{array}$ & $\begin{array}{c}\text { Co-ordinating } \\
\text { Doers }\end{array}$ & $\begin{array}{c}\text { Empowering } \\
\text { Collaborators }\end{array}$ & $\begin{array}{c}\text { Inspiring } \\
\text { Co-creators }\end{array}$ \\
\hline
\end{tabular}

Generation Z, which is known also as Homeland Generation, Post - Millennials and iGeneration, is particularly interesting because the largest amount of young people from this generation is and will be in higher education at least for 15-20 years.

Generation Z (Gen Z) has seven key traits [8]:

1. Phigital (physical + digital trait). The digital world ( $91 \%$ of generation representatives believe that the level of processing complexity of a company affects the desire to work for it).

2. High personalisation level (personal image searching and cultivation; everything surrounding is being personalized; it is also applicable to profession titles and ways of career development).

3. Realistic (pragmatic mindset; it is considered that in order to survive and succeed, you have to reasonably estimate the required efforts).

4. FOMO (fear of missing out)(the fear to miss out something important; new challenges in working environment; $75 \%$ are interested in performing several functions simultaneously at their workplace within the same organisation).

5. Virtual economy (not simple employees; striving to unlock the potential of corporate approach in their socially beneficial activity; $93 \%$ believe that the choice of a company depends on its attitude towards the society).

6. DIY ("do it yourself" principle; believe that they can do a lot themselves; take a stand for their independence; $71 \%$ believe: if you want a thing done well, do it yourself).

7. Driven (motivated generation; competitive generation; big individualists; $72 \%$ believe that they are more competitive that other employees in their field of work).

The five elements that benefit parents and children of Generation $Z$ are [9]: 1) unconditional parental and familial acceptance(accepta person as he/she is in reality); 2) respect towards individuality and personhood; 3) parental wisdom; 4) personal experience grounded in real interpersonal relationships; 5) spending ,real” time together, to develop deeper commitments to each other; digital is ,real time”.

As regards the research on Generation $\mathrm{Z}$ in Latvia, there has been carried out a study at Jelgava secondary school No. 5.The study was on motives of the choice of a profession and work values. 55 respondents (belonging to Generation $\mathrm{Z}$ ) from forms 11 (29 respondents) and 12 (26 respondents) participated in the study. They will finish school and will be engaged in learning or work from 2018 and 2019. The main work values marked by the students from the form 11 are the following: 1) salary; 2) diversity; 3) independent learning; 4) safety; 5 - 6) duties;relations; 7) independence. It means that students wish to have well-paid work, diversity in the frame of a chosen profession. They are aware of the importance of independent learning and safety of work environment. Friendly relations at work and independence also are of high importance.

The main values marked by the students of the form 12 are the following: 1-2) autonomy; safety; 3) salary; 4) success; 5) support; 6-7) responsibility;social status.

It is possible to conclude from the answers of the 12th form students that the students, who will continue their education in various programmes getting profesion both in Latvia and abroad, want to be autonomous, i.e. to act independently, work in well equipped and safe environment, receive good 
salary, get success, support their colleagues, take a responsibility (be independent) and take an appropriate status in society [10].

The fields of professional choice of Generation $\mathrm{Z}$ will be: engineering sciences, programming, IT, medicine, etc. [5].Generation $\mathrm{Z}$ are full-time students in higher education now and they have their learning needs (Table 1), which determine and foster changes in the study process of higher schools. The changes are going on in the development of attitude, choice of teaching/learning and assessment methods, giving feedback and in the assessment system in general.

Exact disciplines are a part of culture and generation $\mathrm{Z}$ perceives it through its values and peculiarities in the context of information overload. Therefore, there is a view that there are serious teaching difficulties and young people perceive and understand only a small part of information [3;6].This is a problem both of students and educators. The last ones also have to lean intensively in order to reach good or excellent results of their students. Therefore, educators have to know and understand the peculiarities of Generation $\mathrm{Z}$ and analyse themselves as well with the purpose to define further steps of their further education needs.

Two groups of the LLU educators (41 persons) in 2016 and 2017 described themselves versus Generation $\mathrm{Z}$ by the SWOT analysis. The results of two years are compiled into four groups: strong sides, weak sides, opportunities and threats. According to SWOT strong and weak sides reflect inner condition/state and opportunities and treats reflect outer conditions.

The LLU educators recognise that their strong sides are: responsibility and work discipline; readiness to take a moderate risk; life experience and ability to understand others, and develop relationships; domination of mental values; ability to adapt to new technologies; good pedagogues (teach others and learn themselves); usage of interdisciplinary methods and ability to manage the teaching process and some are charismatic as well; flexible persons with emotional intellect, sense of humour and strong nervous system;developed professionals/personalities with life experience, intellect and practical knowledge; constructive approach towards reality; experience in children upbringing; public works; understanding the needs of a target group.

Educators' social (e.g. develop relationship) and professional (e.g. to manage the teaching process) competences dominate in the answers; however, they are twisted with self- competence (e.g. flexible persons with emotional intellect) as well.

Weak sides are sensitive and serious problems, and educators mentioned the following ones: conservativism; stubbornness and sticking only to one point of view; disability to have an impact on things; disability to accept that everything should be pertained here and now often; usage of new information too late; problems how to work with different ages in one group.

Educators recognise their problems and solving of them (at least partly)could be fostered also in the further education courses for the LLU educators.

The LLU educators are quite optimistic towards opportunities. They accept the opportunity to use students' experience and exchange of experience in order to create new knowledge by means of ability to memorise/analyse and complement their experience; usage of innovations and development of thinking, and distribution of works finding the most appropriate person; looking for additional motivation and abilities to understand; training of tolerance and recognition of mistakes; adapt to thinking (try to understand) of Generation Z; adapt ones activities to student needs; to develop together because both younger and older could be wise persons.

Despite of the opportunities, the LLU educators speak a lot about threats emphasizing different perception abilities and usage of technologies in different age groups and therefore educators have serious difficulties to adapt to students' knowledge and perception level in such groups; students' opinions differ from educators' on final assessment and assessment in general; dislike and misunderstandings among various ages in the frame of one group, e.g., younger generations risk to be misunderstood and older generations lack skills in ICT usage as well as different opinions about selfevident things; too low/high self-esteem; canals of getting information and abilities to do it (IT skills); inappropriate teaching methods; lack of ability to perceive the logic of information; lack of understanding the subculture of generations; different cognition/learning styles; different values and ways of communication. 
The survey of 77 first year LLU engineering students had been carried out on self-assessment of spending time in the Internet, relations with authoritarian teachers and expression of ideas freelyin 2016.The results are depicted in Table 2.

Table 2

First year students' self-assessment

\begin{tabular}{|c|l|c|c|c|c|}
\hline \multicolumn{2}{|c|}{ Indicator } & Respondents & \multicolumn{3}{|c|}{ Self-assessment } \\
\cline { 3 - 6 } & Totally & high & middle & low \\
\hline A & I spend time in the Internet & $\mathbf{7 7}$ & $\mathbf{8}$ & $\mathbf{5 1}$ & $\mathbf{1 8}$ \\
\hline B & $\begin{array}{l}\text { I have good relations with } \\
\text { authoritarian teachers }\end{array}$ & 77 & 6 & $\mathbf{5 5}$ & $\mathbf{1 6}$ \\
\hline C & $\begin{array}{l}\text { It is important for me to } \\
\text { express my ideas freely }\end{array}$ & $\mathbf{7 7}$ & $\mathbf{3 8}$ & $\mathbf{3 5}$ & 4 \\
\hline
\end{tabular}

Statistical significance $(p<0.01)$ among A, B and C assessment distributions was determined. Assessments middledominate in A and B distributions and differences of A and B are not statistically significant $(p>0.76)$. In distribution $\mathrm{C}$ assessments high dominate. $\mathrm{C}$ differs from A or B assessments distribution significantly. There is a small number of low assessments and high and middle assessments dominate in distribution $\mathrm{C}$.

Engineering students spend time in the Internet both for learning and free time activities, but the high level is only to eight first year students (assessments distribution A). They also had been quite tolerant towards authoritarian teachers at school, although 16 of 77 students answered that they lack good relations with this type of teachers (assessment distribution B), and there is a tendency that Generation $\mathrm{Z}$ will become more demanding towards democratic relations from both sides.As regards assessment distribution $\mathrm{C}$, Generation $\mathrm{Z}$ is tended to express their thoughts and is not ready to take information, but generate it.

All the three assessment distributions are only a quite small case study in one university; therefore, further investigations should be dedicated to Generation $\mathrm{Z}$ values, interpersonal relation models and learning ways.

\section{Conclusions}

1. Generation $\mathrm{Z}$ will have a serious attitude towards career development and it will be interested in multifunctional activities at work/organization. The empirical study reflects that this theoretical statement refers to the students of form 12 as well.

2. The fields of keen interest of Generation $\mathrm{Z}$ will be the disciplines of engineering sciences, IT and medicine. This statement is not unequivocal andhas to be investigatedin Latvia's situation, because a lot of state granted budget places remain vacant in the programmes of exact and also of engineering sciences every year.

3. Generation $\mathrm{Z}$ is quite social and ready to acquire and use technologies. It is very important for Generation $\mathrm{Z}$ to express their opinions and generate ideas. Generation $\mathrm{Z}$ is active, kinesthetic and able to involve in creation of knowledge instead of being passive listeners or observers. It means that discussions, projects, group work and other interactive methods, as well as usage of technologies should be a part of engineering studies.

4. Comparing the survey results from the secondary school students of form 12, the LLU students and educators, it is possible to conclude that autonomous, responsible and creative action is typical to the respondents and they try to develop competence, get good salary and an appropriate status in the society. It means that students will be more demanding towards educators in order to be competitive on national and international level. Although the educators are experienced, professional and responsible, they are obliged to adapt to rapidly changing technological progress and peculiarities of Generation $\mathrm{Z}$ in order to be competitive in the field of teaching in higher education.

5. Educators recognize their problems and solving of them (at least partly) could be fostered also in the further education courses for the LLU educators.Interactive methods, usage of IT, knowledge 
about Generation $\mathrm{Z}$ and training of communication should be included and developed in the further education course content of the LLU educators.

\section{References}

[1] System Initiatives. World Economic Forum 2018. [online] [03.03.2018]. Available at: https://www.weforum.org/system-initiatives

[2] Shaping the Future of Education, Gender and Work. World Economic Forum 2018. [online] [03.03.2018]. Available at: https://www.weforum.org/system-initiatives/shaping-the-future-ofeducation-gender-and-work

[3] McCrindle M. Generation - Defined - Sociologically, 2012.[online] [21.01.2018]. Available at:http://mccrindle.com.au/resources/Generations-Defined-Sociologically.pdf

[4] Seemiller C., Grace M. Generation Z Goes to College. San Francisco, Jossey Bass, 2016

[5] Robinson M.T. The Generation. Which generation a You? [online] [03.03.2018]. Availableat: https://www.careerplanner.com/Career-Articles/Generations.cfm

[6] Сапа А.В. Поколение Z - поколение эпохи ФГОС. Инновационные проекты и прграммы в образовании (Generation $\mathrm{Z}$ - generation of an eraFSES. Innovative projects and program), 2, 2014, c. 24-30(In Russian)

[7] Stanišauskienė V., Naseckaitė A. Karjeros Vadovas. Mokinio knyga (Career Guide. Pupil's book),2012.(In Lithuanian)[online] [05.09.2017]. Available at: http://www.mukis.lt/lt/mokinio_knyga.html

[8] Stillman D.\&Stillman J. Gen Z Work: How the Next Generation Is Transforming the Workplace. Harper Collins Publishers, 2017.

[9] Zarra E. J. III. Helping Parents Understand the Minds and Hearts of Generation Z. LanhamBoulder- NewYork - London, Rowman\&Littlefield, 2017.

[10]Bistricka D. Profesijas izvēles motīvi un darba vērtības jauniešu un agrīnā brieduma vecumposmos (The Motives for Choosing a Job and the Value of Work at the Young and Early Stages of Adulthood).Zinātniski pētnieciskais darbs. Jelgava, 2018, 26lpp. (In Latvian) 